\title{
PELAKSANAAN SUPERVISI PEMBELAJARAN SEBAGAI UPAYA MENINGKATKAN TUGAS DAN PERAN GURU DALAM MENGAJAR
}

\author{
Ubabuddin \\ Institut Agama Islam Sultan Muhammad Syafiuddin Sambas \\ E-mail: ubabuddin@gmail.com
}

\begin{abstract}
Abstrak
Pembinaan profesi guru salah satunya dilakukan dengan pelaksanaan supervisi. Supervisi adalah segala usaha pejabat sekolah dalam memimpin guru-guru dan tenaga kependidikan lainnya, untuk memperbaiki pengajaran termasuk menstimulasi, menyeleksi pertumbuhan dan perkembangan jabatan guru-guru, menyeleksi dan merevisi tujuan-tujuan pendidikan, bahan pengajaran, dan metode-metode mengajar serta evaluasi pengajaran. Supervisi di sekolah dilaksanakan oleh kepala sekolah yang bertindak sebagai supervisor, maka ia harus mampu melakukan berbagai pengawasan dan pengendalian untuk meningkatkan kinerja guru. Peran supervisor adalah memberikan bimbingan, arahan, dan tuntunan proses belajar mengajar guru demi perbaikan. Langkahlangkah perbaikan ini ditujukan agar proses belajar mengajar serta peran dan tugas guru semakin profesional.
\end{abstract}

Kata Kunci: Supervisi Pembelajaran, Tugas dan Peran Guru, Mengajar

\begin{abstract}
One of the ways in which the teacher profession is developed is by conducting supervision. Supervision is all the efforts of school officials in leading teachers and other education personnel, to improve teaching, including stimulating, selecting the growth and development of teacher positions, selecting and revising educational goals, teaching materials, and teaching methods and teaching evaluation. Supervision in schools is carried out by the principal who acts as a supervisor, so be must be able to carry out a variety of supervision and control to improve teacher performance. The supervisor's role is to provide guidance, direction, and guidance for the teacher's teaching and learning process for improvement. These improvement steps are intended to make the teaching and learning process and the roles and tasks of the teacher more professional.
\end{abstract}

Keywords: Supervision of Learning, Tasks and Roles of Teachers, Teaching 


\section{PENDAHULUAN}

Peningkatan mutu pendidikan selalu diupayakan, Pembenahan itu dilaksanakan di segala bidang antara lain berupa sarana atau fasilitas, perubahan kurikulum, dan peningkatan kualitas pendidik.

Apabila kita perhatikan tujuan pendidikan, yaitu membentuk manusia Indonesia seutuhnya dalam arti tersedianya SDM yang berkualitas, maka harus didukung sarana, kurikulum dan tenaga pendidik yang profesional yaitu yang mampu menjawab tantangan pendidikan di era globalisasi saat ini. Profesionalisme pendidik akan bisa ditingkatkan bila didukung dengan adanya pengawasan, pembinaan dan pemberian bimbingan yang baik (Fajriana \& Aliyah, 2019). Kegiatan utama pendidikan di sekolah dalam rangka mewujudkan tujuan tersebut adalah kegiatan pembelajaran sehingga seluruh aktivitas organisasi sekolah bermuara pada pencapaian efisiensi dan efektivitas pembelajaran (Kartiko \& Azzukhrufi, 2019).

Tugas pokok guru adalah menyusun perencanaan pembelajaran, melaksanakan pembelajaran, dan menilai hasil belajar siswa (Maarif \& Rofiq, 2018). Tugas dan tanggung jawab yang harus diakukan oleh seorang guru yaitu rangkaian mengajar, memberikan dorongan, memuji, memberikan contoh, dan membiasakan (U, 2015). Tugas dalam mendidik merupakan rangkaian dari proses belajar mengajar, memberikan dorongan, memuji, memberi contoh dan membiasakan (Darmadi, 2016). Agar mutu pendidikan dapat dicapai secara optimal, maka pelaksanaan tugas pokok guru tersebut harus mendapat pengawasan, baik dari pengawas maupun kepala sekolah (Fauzi, 2017). Pengawasan proses pembelajaran adalah salah satu bentuk penjaminan mutu yang dilakukan secara internal (sekolah) untuk memberikan layanan bagi terjadinya proses pembelajaran yang efektif dan efisien (Hamdi, 2019; Wahib, 2018). Sebagai bentuk pengawasan eksternal oleh pengawas, supervisi juga dapat difungsikan sebagai pengawasan internal, pengawasan proses pembelajaran menjadi tanggung jawab Kepala Sekolah selaku supervisor pembelajaran .

Sehubungan dengan itu, Kepala sekolah sebagai supervisor berfungsi untuk mengawasi, membangun, mengoreksi dan mencari inisiatif terhadap jalannya seluruh kegiatan 
pendidikan yang dilaksanakan di lingkungan sekolah (Asyari, 2019). Secara teoritis diartikan sebagai layanan yang bersifat membimbing, memfasilitasi, memotivasi serta menilai guru dalam pelaksanaan pembelajaran dan pengembangan profesinya seara efektif (Ubabuddin, 2019).

Dengan demikian, supervisi ditujukan kepada penciptaan atau pengembangan situasi belajar mengajar yang lebih baik. Untuk itu ada dua hal (aspek) yang perlu diperhatikan: pertama, pelaksanaan kegiatan belajar mengajar; dan kedua, hal-hal yang menunjang kegiatan belajar mengajar.

\section{Konsep Dasar Supervisi Pembelajaran}

\section{Pengertian Supervisi Pembelajaran}

Supervisi berasal dari kata super dan visi yang artinya melihat dan meninjau atau menilik dan menilai dari atas yang dilakukan oleh pihak atasan terhadap aktivitas, kreativitas, dan kinerja bawahan (Jamal Ma`mur, 2012). Selanjutnya AN Ametembun mengungkapkan bahwa: "Supervisi diambil dari perkataan Inggris supervision artinya pengawasan. Lebih lanjut diungkapkan bahwa istilah supervisi dapat pula dijelaskan menurut arti morfologis, supervisi terdiri dari dua patah kata yakni super dan visi. Super artinya atas dan visi artinya lihat, tilik, awasi. Seorang supervisor memang mempunyai posisi di atas atau mempunyai kedudukan yang lebih tinggi dari pada orang-orang yang disupervisinya" (Ametembun, 1991).

$$
\text { Pengertian lain supervisi }
$$

pembelajaran diartikan sebagai pelayanan yang disediakan oleh pemimpin untuk membantu guru-guru agar menjadi guru atau personal yang semakin cakap sesuai dengan perkembangan ilmu pengetahuan pada umumnya dan ilmu pendidikan khususnya, agar mampu meningkatkan efektivitas proses belajar mengajar di sekolah (Nawawi, 1988).

Menurut Ngalim (Purwanto, 1987) supervisi adalah suatu aktivitas pengawasan dan pembinaan yang direncanakan untuk membantu para guru dan pegawai sekolah lainnya dalam melakukan pekerjaan mereka secara efektif. Surya (Dharma, 2008) dalam jurnalnya mengungkapkan: "Menurut konsep tradisional, supervisi dilaksanakan dalam bentuk inspeksi atau mencari kesalahan. Sedangkan dalam pandangan modern, supervisi merupakan usaha untuk memperbaiki situasi pendidikan atau pembelajaran, yakni sebagai bantuan bagi pendidik untuk meningkatkan kemampuan profesionalisme sehinnga peserta didik akan lebih berkualitas. Konsekuensi prilaku supervisi tradisonal atau snooper vision adalah 
para staf pengajar akan menjadi takut dan mereka bekerja secara terpaksa serta mengurangi/mematikan kreativitas guru/dosen dalam pengembangan profesionalismenya".

Atas dasar uraian di atas, maka pengertian supervisi dapat dirumuskan sebagai serangkaian usaha pemberian bantuan kepada guru dalam bentuk layanan profesional yang diberikan guna meningkatkan mutu proses dan hasil belajar mengajar. Pembinaan guru lebih menekankan pada pembinaan kinerja guru yakni pembinaan yang lebih diarahkan pada upaya memperbaiki, memotivasi dan meningkatkan kemampuan kinerja guru dalam mendidik atau menyampaikan pembelajaran kepada peserta didik.

Aspek-aspek tersebut menuntut pengetahuan tentang konsep-konsep dan pendekatan supervisi yang ditunjang dengan kinerja serta akuntabilitas yang tinggi dari supervisor. Hal ini dimaksudkan agar kegiatan supervisi sebagai layanan profesional dapat meningkatkan kompetensi guru dalam pembelajaran yang bermuara pula pada perwujudan hasil belajar peserta didik secara optimal.

\section{Tujuan Supervisi Pembelajaran}

Pelaksanaan supervisi adalah bertujuan untuk memberikan bantuan teknis dan bimbingan kepada guru dan staf agar personil tersebut mampu meningkatkan kualitas kinerjanya, dalam melaksanakan tugas dan melaksanakan proses belajar mengajar. Secara operasional dapat dikemukakan beberapa tujuan konkrit dari supervisi sebagaimana yang dipaparkan oleh Makawimbang (Jerry H, 2011) yaitu:

a. Meningkatkan mutu kinerja guru.

b. Meningkatkan keefektifan kurikulum sehingga berdaya guna dan terlaksana dengan baik.

c. Meningkatkan keefektifan dan keefisian sarana dan prasarana yang ada untuk dikelola dan dimanfaatkan dengan baik sehingga mampu mengoptimalkan keberhasilan siswa.

d. Meningkatkan kualitas pengelolaan sekolah khususnya dalam mendukung terciptanya suasana kerja yang optimal dan selanjutnya siswa dapat mencapai prestasi belajar sebagaimana yang diharapkan.

e. Meningkatkan kualitas situasi umum sekolah sehingga tercipta situasi yang tenang dan tentram serta kondusif yang akan meningkatkan kualitas pembelajaran yang menunjukkan 
keberhasilan lulusan.

Sedangkan Bafadal (Ibrahim, 2008) mengungkapkan bahwa tujuan supervisi adalah untuk membantu guru mengembangkan kemampuannya, mencapai tujuan pengajaran yang dicanangkan bagi murid-muridnya. Ibnu (Syamsi, 1983) bahwa tujuan supervisi, yaitu untuk mengetahui:

a. Apakah suatu pelaksanaan itu berjalan sesuai dengan rencana yang telah digariskan?

b. Apakah segala sesuatu dijalankan sesuai dengan instruksinya?

c. Kelemahan dan kesulitan dalam bekerja?

d. Mencari jalan keluar, bilamana terdapat kesulitan-kesulitan dan diusahakan pemecahannya.

Dalam usaha meningkatkan kualitas sumber daya pendidikan, guru merupakan komponen utama yang harus dibina dan dikembangkan terus menerus, sehingga dapat meningkatkan kinerja guru di sekolah. Disini dibutuhkan supervisor untuk mensupervisi semua persoalan yang muncul bagi guru dengan tujuan memberikan bantuan perbaiakan-perbaikan dengan semestinya. Dengan merefleksi semua tujuan inilah supervisi akan berfungsi dengan baik dan dapat mengubah perilaku mengajar dan meningkatkan kinerja guru. Pada gilirannya nanti perubahan perilaku mengajar dan kinerja guru ke arah yang lebih berkualitas akan menimbulkan perilaku belajar murid yang lebih baik.

\section{Fungsi Supervisi Pembelajaran}

Fungsi supervisi pembelajaran adalah untuk memperbaiki situasi pembelajaran melalui pembinaan profesionalisme guru. Briggs dalam (Sahertian, 2000), menyebutkan fungsi supervisi sebagai upaya mengkoordinir, menstimulir dan mengarahkan pertumbuhan guru-guru. Supervisi pembelajaran memiliki fungsi penilaian (evaluation) yaitu penilaian kinerja guru dengan jalan pengamatan, yakni mengumpulkan informasi dan fakta-fakta mengenai kinerja guru dengan cara melakukan pengamatan. Kegiatan evaluasi dan pengamatan ini merupakan usaha perbaikan, sehingga berdasarkan data dan informasi yang mestinya sehingga dapat meningkatkan kualitas kinerja guru dalam pembelajaran.

Dari uraian diatas dapat disimpulkan bahwa fungsi supervisi pembelajaran mencakup: (1) perbaikan, (2) pengamatan atau penelitian, (3) pembinaan, 
(4) pengembangan, (5) koordinasi, (6) memotivasi, dan (7) penilaian.

\section{Prinsip-prinsip Supervisi Pembelajaran}

Seorang supervisor dalam melaksanakan supervisi hendaknya senantiasa menerapkan prinsip-prinsip supervisi sebagai berikut:

1. Prinsip Ilmiah dengan unsur-unsur:

a. Sistematis, berarti dilaksanakan secara teratur, berencana dan kontinyu.

b. Obyektif, artinya data yang didapat berdasarkan pada observasi nyata, bukan tafsiran pribadi.

c. Menggunakan alat (instrumen) yang dapat memberikan informasi sebagai umpan balik untuk mengadakan penilaian terhadap proses belajar mengajar.

2. Demokratis, menjunjung tinggi atas musyawarah.

3. Kooperatif/kemitraan, seluruh staf dapat bekerjasama, mengembangkan usaha dalam menciptakan situasi pembelajaran dan suasana kerja yang lebih baik.

4. Konstruktif dan kreatif, membina inisiatif staf/guru serta mendorong untuk aktif menciptakan suasana agar setiap orang merasa aman dan dapat mengembangkan potensi-potensinya

(Masaong, 2013).

\section{Tugas dan Fungsi Supervisor}

Tugas seorang supervisor yang perlu dipahami bahwa kegiatan apapun yang dilakukannya bertujuan untuk memperbaiki proses dan hasil belajar mengacu pada terjadinya perubahan perilaku mengajar guru ke arah yang lebih baik. Untuk itu seorang supervisor harus memahami tugas dan fungsi sebagai supervisor seperti bagan di bawah ini:

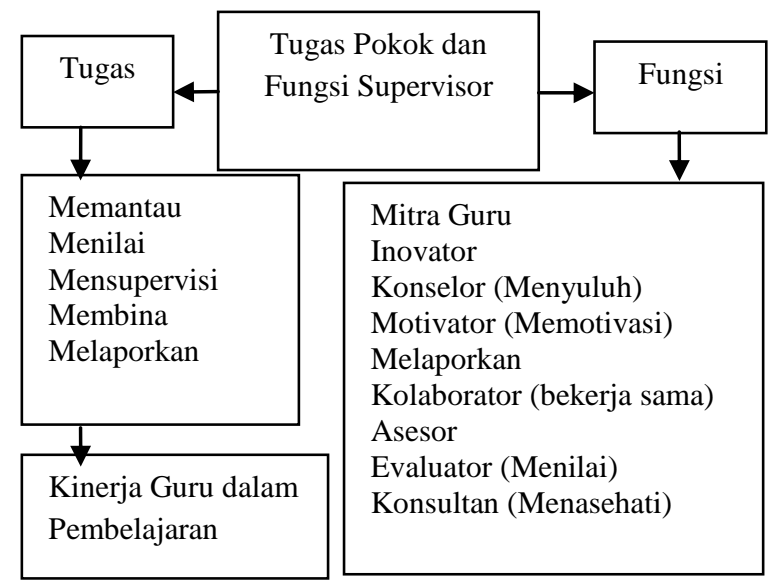

Gambar 2.1 Tugas Supervisi

Sumber: Aqib 2009

Tugas Pokok dan Fungsi Supervisor (Aqib, 2009)

Dalam suatu analisa fungsi supervisi yang diberikan oleh swearingen yang dikutip Sahertian(Sahertian, 2000), terdapat 8 fungsi supervisi, yakni:

a. Mengkoordinasi Semua Usaha Sekolah. 
Koordinasi yang baik diperlukan terhadap semua usaha sekolah untuk mengikuti perkembangan sekolah yang makin bertambah luas dan usaha-usaha sekolah yang makin menyebar, diantaranya: Usaha tiap guru, Usaha-usaha sekolah, Usahausaha pertumbuhan jabatan.

b. Memperlengkapi Kepemimpinan Sekolah.

Yakni, melatih dan memperlengkapi guru-guru agar mereka memiliki ketrampilan dan kepemimpinan dalam kepemimpinan sekolah.

c. Memperluas Pengalaman.

Yakni, memberi pengalamanpengalaman baru kepada anggotaanggota staff sekolah, sehingga selalu anggota staff makin hari makin bertambah pengalaman dalam hal mengajarnya.

b. Menstimulasi Usaha-Usaha yang Kreatif.

Yakni, kemampuan untuk menstimulir segala daya kreasi baik bagi anak-anak, orang yang dipimpinnya dan bagi dirinya sendiri.

e. Memberikan Fasilitas dan Penilaian yang Kontinyu.

Penilaian terhadap setiap usaha dan program sekolah misalnya, memiliki bahan-bahan pengajaran, buku-buku pengajaran, perpustakaan, cara mengajar, kemajuan muridmuridnya harus bersifat menyeluruh dan kontinyu.

\section{f. Menganalisa Situasi Belajar}

Situasi belajar merupakan situasi dimana semua faktor yang memberi kemungkinan bagi guru dalam memberi pengalaman belajar kepada murid untuk mencapai tujuan pendidikan.

g. Memberi Pengetahuan dan Ketrampilan pada Setiap Anggota Staf.

Supervisi berfungsi memberi stimulus dan membantu guru agar mereka memperkembangkan pengetahuan dan keterampilan dalam belajar.

h. Mengintegrasikan Tujuan dan Pembentukan Kemampuan.

Fungsi supervisi di sini adalah membantu setiap individu, maupun kelompok agar sadar akan nilai-nilai yang akan dicapai itu, memungkinkan penyadaran akan kemampuan diri sendiri.

Menurut (Ametembun, 1991) menyatakan seorang supervisor hendaknya melakukan fungsi-fungsinya sebagai berikut: 
a. Penelitian, untuk memperoleh gambaran yang jelas dan objektif tentang suatu situasi pendidikan maka perlu diadakan penelitian yang seksama terhadap situasi itu.

b. Penilaian, supervisor dalam hal ini dapat menarik kesimpulan terhadap hasil penelitian yang diselidiki. Kesimpulan berupa tanggapan terhadap masalah atau situasi yang diselidiki itu dan terus melakukan penilaian. Fungsi penilaian atau evaluasi dalam hal ini adalah lebih menitik beratkan pada aspekaspekpositif (kebaikan-kebaikan) dari aspek-aspek negatif.

c. Perbaikan, dari hasil penelitian itu supervisor dapat mengetahui bagaimana keadaan suatu situasi pendidikan/pengajaran pada umumnya dan pendidikan/pengajaran pada khususnya, serta segala fasilitas dan daya upaya yang dipergunakan, apakah baik atau buruk, memuaskan atau tidak, mengalami kemajuan atau kemunduran, atau mengalami kemacetan dan sebagainya.

d. Peningkatan, bagaimana dengan situasi yang sudah baik, sudah memuaskan, telah mengalami kemajuan itu. Situasi yang demikian harus ditingkatkan atau dikembangkan agar apa yang sudah memuaskan itu supaya lebih memuaskan lagi.

Sejalan dengan fungsi supervisor diatas, Jerry H. Makawimbang (Jerry H, 2011) membagi fungsi supervisor menjadi fungsi umum dan fungsi khusus, seperti berikut ini:

a. Fungsi Umum Supervisor

1) Pemantauan

2) Penyeliaan (supervision)

3) Pengevaluasian

4) Penindak lanjutan hasil pengawasan

b. Fungsi Khusus Supervisor

Kemitraan, pembaharuan, pemeloporan, konsultan, pembimbingan, pemotivasian, pengonsepan, pemrograman, penyusunan, pelaporan, pembinaan, pendorongan, pemantauan, pemanfaatan, pengawasan, pengkoordinasian, dan pelaksanaan kepemimpinan.

Seorang supervisor perlu memahami dengan jelas fungsi supervisi akademik yang dipercayakan kepadanya dalam usaha kearah tercapainya tujuan. Sehingga pelaksanaan supervisi yang dilaksanakan oleh supervisor dapat 
berjalan sesuai dengan perencanaan yang disusun

\section{Tugas dan Peran Guru}

\section{Tugas Guru sebagai Profesi}

Tugas guru sebagai profesi dalam melaksanakan kegiatan belajar mengajar merupakan tugas utama. Pekerjaan ini tidak bisa sembarangan dilakukan oleh orang yang bukan ahli di bidang kependidikan.

Menurut Nasution dalam (Jasmani \& Syaiful, 2013) menyebutkan bahwa: 1) mengajar ialah menanamkan pengetahuan kepada murid, 2) menyampaikan kebudayaan kepada anak, 3) aktivitas mengorganisasikan atau mengatur lingkungan dengan sebaik-baiknya dan menghubungkan dengan anak sehingga terjadi proses belajar-mengajar.

Proses belajar merupakan inti dari proses pendidikan secara keseluruhan dengan guru sebagai pemegang peran utama. Proses belajar merupakan suatu proses yang mengandung serangkaian perbuatan guru dan siswa atas dasar hubungan timbal balik yang berlangsung dalam situasi edukatif untuk mencapai tujuan tertentu.
Sebagai seorang demonstrator guru hendaknya senantiasa menguasai bahan atau materi pelajaran yang akan diajarkan serta senantiasa mengembangkannya dalam artian meningkatkan kemampuannya terhadap keilmuan yang dimilikinya, sehingga seorang guru harus selalu belajar hal-hal baru yang belum diketahuinya. Pembelajaran yang berkualitas adalah pembelajaran yang mampu meningkatkan aktivitas, disiplin belajar, dan motivasi belajar peserta didik. Dengan demikian suasana pembelajaran akan diwarnai oleh keterlibatan aktif peserta didik baik fisik, mental, maupun sosial, di samping kegairahan belajar yang tinggi, semangat belajar yang besar, dan rasa percaya diri sendiri yang tinggi.

\section{Persiapan dan Keterampilan Dasar} KBM

\section{Persiapan Mengajar}

Guru sebagai pelaksana kegiatan belajar mengajar diharuskan mempersiapkan segala sesuatu yang berhubungan dengan jalannya pembelajaran. Persiapan-persiapan sebelum mengajar dikenal dengan perangkat mengajar dan kesiapan dalam jalannya pembelajaran dikenal dengan keterampilan mengajar. 
Secara implisit dalam pengajaran terdapat kegiatan memilih, menetapkan, dan mengembangkan metode untuk mencapai hasil pengajaran yang diinginkan. Pemilihan, penetapan dan pengembangan metode didasarkan pada kondisi pengajaran yang ada. Lebih lanjut diungkapkan, bahwa istilah pembelajaran memiliki hakikat perencanaan atau desain sebagai upaya untuk membelajarkan siswa (Jasmani \& Syaiful, 2013).

Dengan definisi di atas dapat diambil kesimpulan bahwa, perencanaan atau persiapan perangkat kegiatan belajar mengajar sangat penting dilakukan dalam kerangka keterarahan, keefektifan, dan keefisiensian dalam pelaksanaan pembelajaran. Sedangkan persiapan-persiapan sebelum melaksanakan pembelajaran oleh seorang guru yaitu pembatan program tahunan (prota), pembuatan program semesteran (prosem), pembuatan perangkat mengajar (silabus, RPP), dan persiapan batasan mengajar. Inilah yang harus dipersiapkan oleh seorang guru dalam melaksanakan proses belajar mengajar, karena tanpa perangkatperangkat tersebut akan berpengaruh besar terhadap tujuan yang ingin dicapai.

\section{Keterampilan Dasar Mengajar}

Keterampilan mengajar memiliki peran yang sangat penting dalam mencapai tujuan pembelajaran. Keterampilan mengajar terkait erat dengan pelaksanaan penyampaian pengajaran. Di bawah ini beberapa keterampilan dasar mengajar yang harus dimiliki oleh guru.

1. Keterampilan Bertanya

Dalam proses belajarmengajar, bertanya memainkan peranan penting. Sebab pertanyaan yang tersusun dengan baik dan teknik pelontaran yang tepat pula akan memberikan dampak positif terhadap siswa, yaitu (1) meningkatkan partisipasi siswa dalam kegiatan belajar mengajar, (2) membangkitkan minat dan rasa ingin tahu terhadap masalah yang sedang dibahas, (3) mengembangkan pola dan cara belajar aktif, (4) menentukan proses berpikir siswa, (5) memusatkan perhatian siswa terhadap masalah yang sedang dibahas Jasmani \& Syaiful, 2013).

2. Keterampilan Memberi penguatan Penguatan adalah segala bentuk respons, apakah bersifat verbal ataupun nonverbal, yang merupakan bagian dari modifikasi 
tingkah laku guru terhadap tingkah laku siswa yang bertujuan untuk memberikan informasi atau umpan balik bagi siswa atas perbuatannya sebagai suatu tindak, dorongan, ataupun koreksi (Jasmani \& Syaiful, 2013).

Tujuan
penguatan adalah meningkatkan
perhatian siswa, merangsang,
meningkatkan motivasi belajar,
meningkatkan kegiatan belajar, dan
membina tingkah laku yang
produktif. Sementara prinsip
penguatan adalah kehangatan,
kebermaknaan, kedekatan,
memunculkan keberanian siswa,
menghindari penggunaan respons
yang negatif serta keterampilan
mengadakan variasi.

3. Keterampilan Menjelaskan

Keterampilan menjelaskan dalam pengajaran adalah penyajian informasi secara lisan yang diorganisasikan secara sistematik untuk menunjukkan adanya hubungan yang satu dengan yang lainnya. Tujuan memberikan penjelasan antara lain membimbing siswa untuk memahami fakta dan prinsip seara objektif dan bernalar, (2) berpikir dalam memecahkan masalah atau pertanyaan, (3) untuk mendapatkan balikan dari siswa mengenai tingkat pemahamannya dan mengatasi kesalah pahaman, (4) membimbing siswa untuk menghayati dan mendapat proses penalaran dan menggunakan bukti-bukti dalam pemecahan masalah (Jasmani \& Syaiful, 2013).

4. Keterampilan Membuka dan Menutup Pengajaran

Keterampilan membuka pengajaran adalah bagian dari kegiatan belajar mengajar yang dilakukan guru untuk menciptakan suasana sikap mental dan menimbulkan perhatian siswa agar terpusat pada hal-hal yang akan dipelajarinya atau membangkitkan minat agar siap memasuki persoalan yang akan dipelajari atau dibicarakan. Sementara menutup pelajaran adalah kegiatan yang dilakukan oleh guru untuk mengakhiri pelajaran atau kegiatan belajar mengajar. Usaha menutup pelajaran dimaksudkan untuk memberikan gambaran menyeluruh tentang apa yang dipelajari siswa, mengetahui tingkat pencapaian siswa dan tingkat keberhasilan guru dalam proses 
belajar mengajar(Jasmani \& Syaiful, 2013). Bentuk usaha mengakhiri kegiatan belajar mengajar adalah merangkum atau membuat garis-garis besar persoalan yang dibahas, mengonsolidasikan perhatian siswa terhadap hal-hal yang pokok dalam pelajaran, mengorganisasikan semua kegiatan atau pelajaran yang telah dipelajari dan memberikan tindak lanjut berupa saran-saran serta ajakan.

5. Keterampilan Mengelola Kelas

Pengelolaan kelas adalah keterampilan guru untuk menciptakan dan memelihara kondisi belajar yang optimal dan mengembalikannya bila terjadi gangguan dalam proses belajar mengajar. Suatu kondisi belajar yang optimal dapat tercapai jika guru mampu mengatur siswa dan sarana pengajaran serta mengendalikan dalam suasana yang menyenangkan untuk mencapai tujuan pengajaran (Jasmani \& Syaiful, 2013).

\section{Pelaksanaan Supervisi}

\section{Proses Kepemimpinan dalam Supervisi}

\section{Pembelajaran}

Proses

pelaksanaan

kepemimpinan dalam supervisi di sekolah adalah dengan menganalisis kebutuhan peseta didik, penentuan prioritas terhadap kebutuhan atau urgen, mendesain urutan kegiatan secara selektif, menetapkan alokasi jumlah tenaga, waktu dan pembiayaan dalam urutan prioritas. Beberapa studi kepemimpinan mengemukakan untuk dapat memelihara dan mengandalkan perubahan dalam penyelenggaraan organisasi sekolah mencakup: penilaian, penentuan prioritas, penyusunan desain, penetapan alokasi sumber-sumber, koordinasi dan pengarahan (Masaong, 2013). Tahapan-tahapan di atas hendaknya dilakukan dalam pelaksanaan supervisi pembelajaran. Kaitannya dengan kepemimpinan, kepala sekolah melakukan pembinaan baik yang berhubungan dengan kegiatan akademik maupun yang berkaitan dengan manajerial. 


\section{Kompetensi Pengawas Pendidikan}

Setiap pekerjaan profesional menuntut adanya standar kompetensi yang dipersyaratkan agar tugas-tugas profesi berjalan secara efektif. Sebagai profesi yang menuntut keahlian, maka seorang pengawas dituntut memiliki pendidikan khusus yang tinggi dan rangkaian latihan intensif berkaitan dengan supervisi. Profesi pengawas harus dipahami sebagai pekerjaan yang menuntut ketekunan.

Pengawas sebagai pekerjaan profesi mempunyai persyaratan jenjang dan jenis pendidikan yang harus dilalui dan dipenuhi agar memiliki kemampuan mumpuni untuk menjalankan tugastugas kepengawasan secara efektif (Masaong, 2013). Wiles dan Bondi dalam (Masaong 2013). menegaskan pengawas profesional dituntut memenuhi kompetensi khusus sebagai: (1) pengembang tenaga pendidik dan kependidikan, (2) pengembang kurikulum, (3) spesialis pembelajaran, (4) mediator dan penghubung orang tua siswa, guru, staf dan stakeholder sekolah lainnya, (5) pengembang staf, (6) seorang administrator, (7) manajer perubahan, dan (8) seorang evaluator.

\section{Urgensi Pembinaan Guru}

Pembinaan profesi guru penting dilakukan untuk mendapatkan tenaga pendidik yang profesional. Upaya pembinaan dapat dilakukan dari tenaga pendidik itu sendiri yaitu dia harus benar-benr memiliki motif, tekad, dan semangat yang besar untuk mengabdi dan melaksanakan tugas mendidik dan mengajar bagi bangsanya. Harus pula memiliki kesadaran bahwa profesi guru adalah profesi yang paling luas cakupan, garapan, dan tanggung jawab dari seluruh profesi dan dasar bagi seluruh profesi lainnya. Sementara dari pihak luar adalah peningkatan profesionalisme guru dilakukan oleh para pemegang kebijakan, dalam hal ini dapat dilakukan dengan dua cara, yaitu (1) pelatihan dan pengembangan, (2) pendidikan (Jasmani \& Syaiful, 2013).

\section{Dampak Efektifitas Pelaksanaan} Supervisi

Supervisi dan kegiatan belajar mengajar merupakan dua istilah yang mempunyai makna mendalam serta punya hubungan yang erat dalam proses pendidikan. Supervisi dimaknai secara umum adalah mengamati, mengawasi, membimbing, dan mengarahkan kegiatan-kegiatan orang lain dengan maksud pemberian 
bantuan untuk perbaikan. Belajar berarti proses interaksi antara diri manusia dengan lingkungannya yang mungkin berwujud pribadi, fakta, konsep maupun teori. dalam hal ini terkandung maksud bahwa proses interaksi itu adalah proses internalisasi dari suatu ke dalam diri belajar dan dilakukan secara aktif, dengan segenap panca indera. Sementara mengajar adalah suatu usaha untuk menciptakan kndisi atau sistem lingkungan yang mendukung dan memungkinkan untuk berlangsungnya proses belajar atau suatu aktivitas mengorganisasi atau mengatur lingkungan sebaik-baiknya dan menghubungkan dengan anak didik sehingga terjadi proses belajar.

Dari pengertian di atas dapat diketahui bahwa supervisi belajar mengajar adalah suatu usaha atau kegiatan perbaikan oleh supervisor melalui bimbingan, arahan, petunjuk, pengawasan, dan pengamatan terhadap pengajaran atau pembelajaran yang dilakukan guru di sekolah.

Supervisi memiliki sumbangan terhadap perbaikan pengajaran. Sumbangan supervisi adalah dalam hal perbaikan pengajaran dan teknikteknik prosedur pengajaran. Dengan supervisi, guru diberi kesempatan untuk melatih kemampuan dan kecedasan mereka dalam menggunakan teknik-teknik mengajar, tetapi dibatasi inisiatif dan kreativitas mereka (Jasmani \& Syaiful, 2013). Adapun dampak pelaksanaan supervisi adalah sebagai berikut:

1) Dampak positif meliputi: (1) guru menjadi lebih bergairah, lebih yakin, dan lebih mengenal dengan hasrat dan inisiatif besar mengembangkan dirinya; (2) lebih mampu dalam mewujudkan keahlian atau profesionalnya; (3) menunjukkan kesadaran yang lebih mendalam akan kebutuhan anak didik dan memperbesar kompetensinya untuk memenuhi kebutuhan-kebutuhan itu melalui usaha pendidikan dan pelajaran yang diberikan; menunjukkan ketakwaannya yang maik besar kepada Tuhan Yang Maha Esa dan penunaian ibadah yang diberikan.

2) Dampak negatif meliputi: mengalami keprihatinan, (2) tidak efisien dan kurang bersemangat, (3) sukar menyesuaikan diri, frustasi, dan sebagainya. 


\section{KESIMPULAN}

Supervisi

pembelajaran

bertujuan untuk meningkatkan kemampuan profesional guru dalam proses dan hasil pembelajaran melalui pemberian layanan profesional kepada guru. Tugas pokok guru adalah menyusun perencanaan pembelajaran, melaksanakan pembelajaran, dan menilai hasil belajar siswa. Agar mutu pendidikan dapat dicapai secara optimal, maka pelaksanaan tugas pokok guru tersebut harus mendapat pengawasan, baik dari pengawas maupun kepala sekolah sebagai supervisor.

\section{Pelaksanaan} supervisi pembelajaran diharapkan dapat memperbaiki kualitas pendidikan itu sendiri, sehingga segala bentuk tujuan dapat tercapai secara efektif dan efisien, terutama bagi guru. Karena guru dalam melaksanakan tugas tidak bisa terlepas dari segala bentuk masalah yang dihadapi. Disinilah supervisi pembelajaran sangat dibutuhkan oleh guru, agar dapat membantu menyelesaikan permasalahan yang dihadapinya, serta meningkatkan tugas dan peran guru dalam pembelajaran.

\section{REFERENSI}

Ametembun. (1991). Supervisi Pendidikan: Penuntun bagi para penilik Pengawas Kepala Sekolah dan Guru. Suri Bandung.

Aqib, Z. (2009). Menjadi guru profesional berstandar nasional: Memuat standar nasional pendidikan UURI no. 20/2003 (Sisdiknas), UURI no. 14/2005 (guru dan dosen), PPRI no. 19/2005 (standar nasional pendidikan), PPRI no. 74/2008 (guru), delapan permendiknas (standar nasional pendidikan), Permendiknas no. 10/2009 (sertifikasi bagi guru dalam jabatan), Permendiknas no. 36/2007 (penyaluran tunjangan profesi bagi guru), Permendiknas no. 39/2008 (pembinaan kesiswaan). Yrama Widya.

Asyari, H. (2019). Pemetaan Dan Peningkatan Mutu Pendidikan Pada SMP Bilingual Terpadu Junwangi Krian Sidoarjo. Jurnal Kependidikan, 7(1), 111-126. https://doi.org/10.24090/jk.v7i1.2 239

Darmadi, H. (2016). Tugas, Peran, Kompetensi, Dan Tanggung Jawab Menjadi Guru Profesional. Edukasi: Jurnal Pendidikan, 13(2), 161-174. 
https://doi.org/10.31571/edukasi.

v13i2.113

Dharma, S. (2008). Peranan dan Fungsi

Pengawas Sekolah/Madrasah.

Dalam Jurnal Tenaga Kependidikan, Jakarta: Depdiknas.

Fajriana, A. W., \& Aliyah, M. A. (2019).

Tantangan Guru dalam

Meningkatan Mutu Pendidikan

Agama Islam Di Era Melenial.

Ną̧hruna: Jurnal Pendidikan Islam,

2(2), 246-265.

https://doi.org/10.31538/nzh.v2i2 .324

Fauzi, A. (2017). Kepemimpinan Kepala Madrasah Dalam Mengembangkan Lembaga Pendidikan Islam.

Nidhomul Haq: Jurnal Manajemen Pendidikan Islam, 2(2), 42-53.

Hamdi, A. (2019). Manajemen Mutu

Program Diniyah Pada Pondok Pesantren MuhammadIyah

Lamongan. Nidhomul Haq: Jurnal

Manajemen Pendidikan Islam, 4(2), 247-258.

https://doi.org/10.31538/ndh.v4i2 .463

Ibrahim, B. (2008). Manajemen Peningkatan Mutu Berbasis Sekolah. Kerjasama FIP UM dan Ditjen-Dikdasmen.
Jamal Ma`mur, A. (2012). Tips Efektif Supervisi Pendidikan Sekolah. DIVA Press.

Jasmani, \& Syaiful, M. (2013). Supervisi Pendidikan. Ar-Ruz Media.

Jerry H, M. (2011). Supervisi dan Peningkatan Mutu Pendidikan. Alfabeta.

Kartiko, A., \& Azzukhrufi, jaya R. (2019). Pengaruh Budaya Organisasi Dan Kompensasi Terhadap Kinerja Pendidik Di Madrasah Aliyah Nahdlatul Ulama Mazro'atul Ulum Paciran. Nidhomul Haq: Jurnal Manajemen Pendidikan Islam, 4(2), 207-226. https://doi.org/10.31538/ndh.v4i2 .351

Maarif, M. A., \& Rofiq, M. H. (2018). Pola Pengembangan Kurikulum Pendidikan Pesantren Berkarakter: Studi Implementasi Pendidikan Berkarakter di Pondok Pesantren Nurul Ummah Mojokerto. 13, 16.

Masaong, A. K. (2013). Supervisi pembelajaran dan pengembangan kapasitas guru. Alfabeta.

Nawawi, H. (1988). Administrasi pendidikan. Haji Masagung.

Purwanto, M. N. (1987). Administrasi dan supervisi pendidikan. Remadja Karya.

Sahertian, P. A. (2000). Konsep dasar \& teknik supervisi pendidikan: Dalam 
Nidhomul Haq, Vol 5 No 1 Tahun 2020

rangka pengembangan sumber daya manusia. Penerbit Rineka Cipta.

Syamsi, I. (1983). Pokok-pokok organisasi dan manajemen. PT. Bina Aksara, Jakarta. U, M. S. U. M. S. (2015). Kedudukan Guru Sebagai Pendidik: Tugas Dan Tanggung Jawab, Hak Dan Kewajiban, Dan Kompetensi Guru. Auladuna: Jurnal Pendidikan Dasar Islam, 2(2), 221-232.

Ubabuddin. (2019). Meningkatkan Kinerja Guru Melalui Supervisi Pembelajaran. Ed-Humanistics, 4(1).

Wahib, A. (2018). Penguatan Mutu Madrasah Swasta Menuju Madrasah Unggul. Nidhomul Haq: Jurnal Manajemen Pendidikan Islam, 3(1), $57-70$.

https://doi.org/10.31538/ndh.v3i1 .181 
Nidhomul Haq, Vol 5 No 1 Tahun 2020 